Journal of

\title{
Food and Health Science
}

E-ISSN 2149-0473

ORIGINAL ARTICLE/ORİJíNAL ÇALIŞMA

\section{SUITABILITY OF CORN HUSK AND COW DUNG AS ALTERNATIVES TO FUEL WOOD FOR SMOKING FISH}

\author{
Victoria Offuene AYUBA, Victor Tosin KOMODA, Simon Ihie IKAPE \\ Department of Fisheries and Aquaculture, University of Agriculture Makurdi, Nigeria
}

Received: 25.11 .2014

Accepted: 07.12.2014

Published online: 20.12.2014
Corresponding author:

Victor Tosin OKOMODA, Department of Fisheries and Aquaculture, University of Agriculture Makurdi, NIGERIA

E-mail: okomodavictor@yahoo.com

\begin{abstract}
:
Using fuel wood for fish smoking is literarily becoming very expensive hence the need to find alternative smoking source. This study evaluates the suitability of Cow dung and Corn husks as possible alternatives fish smoking sources to the conventional fuel wood. The results obtained reveals that fish samples smoked with Corn husks had the highest protein level while the least value was observed with Cow dung. Microbial count showed significantly low level in fish smoked with Corn husks $\left(1.2 \times 10^{5}\right)$ compared with the highest level observed in Cow dung $\left(1.81 \times 10^{5}\right)$. Organoleptic assessment revealed fish smoked with Corn husk and Fuel wood to be better in appearance, aroma, taste and texture. Profit analysis indicates it more expensive to smoke $3 \mathrm{~kg}$ fish using Fuel wood ( 2510) compared to Cow dung and Corn husk ( 2210$)$, hence, for profitability and reasons of hygiene, corn husk is strongly recommended for fish smoking above fuel wood and cow dung.
\end{abstract}

Keywords:

Clarias gariepinus, Proximate composition, Organoleptic, Microbial load, Cow dung, Corn husks 


\section{Introduction}

Fish is a very important source of animal protein in the diets of man, it is cheap and highly acceptable, with little or no religious bias, which gives it an advantage over pork or beef (Eyo, 2001). Nigerians are large consumers of fish and it remains one of the main products consumed in terms of animal protein. The fishery sector is estimated to contribute $3.5 \%$ of Nigeria's Gross Domestic Product (GDP) and provides direct and indirect employment to over six million people (Trade Invest Nigeria, 2010). However, only about $50 \%$ of the demand for fish is currently being met by local supply and the gap between the demand and supply of fish is widening due to increase in population, poor post-harvest handling, lack of processing and storage facilities and utilization of unconventional fish species (Ayuba and Omeji, 2006)

Spoilage is a metabolic process that causes food to be undesirable or unacceptable for human consumption due to changes in sensory and nutritional characteristics (Doyle, 2007). The processing and preservation of fresh fish are of utmost importance since fish is highly susceptible to deterioration immediately after harvest and also to prevent economic losses (Okonta and Ekelemu, 2005). If fish is not sold fresh, preservation methods such as freezing, smoking, drying and heat treatment, sterilization, pasteurization, etc. should be applied to extend the shelf-life (Eyo, 2000). Of these preservation methods, smoking or drying fish is traditionally the oldest method and constitute a large section of the diet of the world's population (Okonta and Ekelemu 2005).

Methods of drying and smoking fish vary between different countries and within the same country may differ depending on the species of fish used and the type of product desired (Obande, 2009). Fuel wood is generally used as the conventional smoking source, however, deforestation, competition of purpose with man and emission of green house gases makes alternative means of fish drying other than fuel wood necessary. Hence this study aims at determining the suitability of cow dung and corn husk (Animal and plant waste respectively) as alternatives smoking sources for fish smoking.

\section{Materials and Methods}

Twenty seven matured Clarias gariepinus were purchased from the fisheries research farm of the
University of Agriculture Makurdi (UAM), Benue state, Nigeria. The fish were transported to the Fisheries laboratory in UAM North core, washed thoroughly to remove sand and slime and gutted. The fish were divided in to nine batches: with three batches ( $3 \mathrm{~kg}$ each) smoke-dried using cow dung, fire wood and corn husk. This was replicated. After the drying process, the proximate compositions of fresh and smoked fish samples were carried out according to the official methods described by AOAC (2000). Sensory evaluation was done for the smoked samples by ten panel member to determine Appearance, Aroma/Odour, Taste, and Texture of the smoked fish from different sources. Scores were allotted using the hedonic scale as stated below: Excellent 5, Very Good 4, Good 3, Fair 2, and Poor 1.

Microbial load were evaluated on the samples using the methods specified by FSSAI (2012) and Guinn et al., (1999)

Gross margin analysis was used to measure the net revenue of the three treatments. According to Berman (2006), gross margin was expressed as

\section{$\mathrm{GM}=\mathrm{GR}-\mathrm{TVC}$}

Where: $\mathrm{GM}=$ Gross Margin

$\mathrm{GR}=$ Gross Revenue

$\mathrm{TVC}=$ Total Input Cost

Input used for the gross margin analysis was the cost of fresh Clarias gariepinus, cost of each smoking source, cost of matches and cost of transportation. Data generated were subjected to statistical analysis ANOVA and where significant differences occurred, the means were separated using fishers LSD at $\mathrm{P}<0.05$ ).

\section{Results and Discussion}

The result of weight losses of Clarias gariepinus smoke with the different fuel sources shows that fish smoked with fuel wood and corn husk $(66.67 \%)$ loss the highest weight compared to those smoked with cow dung $(63.33 \%)$. Proximate composition of smoked fish (Table 2) however reveals lowest moisture content in fish sample smoked with Corn husk $(9.42 \pm 0.01 \%)$ while the fresh sample fish had the highest moisture content $(68.58 \pm 0.01 \%)$. The protein content of fresh sample fish were low in crude protein (17.29 $\pm 0.02 \%$ ) while fish smoked with Corn husks had the highest protein level (53.25 $\pm 0.01 \%)$. Lipid 
content of smoked Clarias gariepinus with cow dung and fuel wood was higher compared to corn husk and fresh fish $(16.33 \pm 0.05$ and $5.46 \pm 0.01 \%$ respectively). Ash content of the smoked samples was higher for fuel wood $(5.6 \pm 0.01 \%)$ compared to other fuel sources however the least Ash content was observed in fresh fish.

Fish sample smoked with Cow dung had the highest numbers of bacteria count, $\left(1.81 \times 10^{5} \pm 4.0 \times 10^{2}\right.$ $\mathrm{CFU}$ ) with two organisms grown on it namely Streptococcus gram positive cocci and Bacillus anthracis, gram positive (Table 3). Fish sample smoked with fuel wood had the lowest numbers of bacteria $\left(1.01 \times 10^{5} \quad \pm 1.0 \times 10^{2} \quad \mathrm{CFU}\right)$ with Stapylococcus spp. gram positive identified. Also fish sample smoked with Corn husks had $1.2 \times 10^{5}$ $\pm 3.0 \times 10^{2} \mathrm{CFU}$ numbers of bacteria count with Staphylococus aureus grown.

Fish samples smoked with Fuel wood were concluded to be superior in appearance, aroma, taste and texture by the panel of assessors used, followed by fish samples smoked with Corn husks, while fish samples smoked with Cow dung had the least scores (Table 4).

Gross profit analysis reveals it is more expensive to smoke $3 \mathrm{~kg}$ of Clarias gariepinus fish with Fuel energy source ( $\mathrm{N} 2510$ ) than smoking the same quantity of fish with Cow dung ( 2210) and Corn husk over the same period of time (Table 5, 6 and 7).

Generally, the aim of smoking fish is to reduce the moisture content to about 15-20\% (Eyo, 2001), hence the observed reduction of moisture content of the fresh fish from $68.58 \%$ to the range of $9.42 \%-11.19 \%$ is in line with the above hypothesis. Nerqua ye- Teiteh et al. (2002) reported that different fuel wood reduce the moisture content of
Chrysichthys auratus to between $9-13 \%$ which is in line with the result of the present study it was concluded that this moisture content were low enough to prevent little deterioration problems if storage conditions were properly controlled hence, it is expected that reduced moisture content observed in this study reduce activity of spoilage organism hence prolong the shelf of the fish. OkosoAmaa et al., (1978) indicated that the shelf life of smoked Sardinella spp. varied according to the moisture content. Plahar et al. (1996) recommended an initial smoked fish content below $13 \%$ before storage. They reported that this condition would also not favour the development of aflatoxin-producing moulds. However, at moisture levels of $15 \%$ and above, a great deal of proteolytic and lipolytic deterioration as well as microbial proliferation are favoured (Kaneko, 1976) in contrast to this Olayemi et al. (2011) reported 6$8 \%$ moisture as the recommended safe moisture content of dried fish. However, the effective of this ranges to prolong the self life of fish greatly depend on fish species, duration of smoking, duration of storage, storage technology etc. Fat level of fresh sample and fuel wood smoked fish were quite lower than those recorded for cow dung and corn husk, for storage purposes fuel wood smoked fish may stay longer than other sources used in this study because of rancidity of fat content. The fat levels of $15-33 \%$ are proposed to be high and may cause rancidity problems within a short period of storage by Plahar et al (1991). The crude protein of the smoked fish were quite higher than that obtained in the fresh fish; according to Abdullahi (2011), higher moisture content of fish result into lesser value of crude protein. This may be due to the fact that in fresh fish, the protein is less coagulated than in dried form which is said to increase the digestibility of the protein in fish.

Table 1. Mean weight changes of Clarias gariepinus exposed to different smoked sources.

\begin{tabular}{llllc}
\hline Parameters & $\begin{array}{l}\text { Smoke Sources } \\
\text { Fuel wood }\end{array}$ & Cow dung & Corn husks & P-Value \\
\hline Initial $(\mathrm{g})$ & $3000 \pm 0.1$ & $3000 \pm 0.1$ & $3000 \pm 0.1$ & 0.234 \\
Final weight $(\mathrm{g})$ & $1000 \pm 2.5^{\mathrm{b}}$ & $1100 \pm 10.0^{\mathrm{a}}$ & $1000 \pm 15.0^{\mathrm{b}}$ & 0.001 \\
Weight loss $(\mathrm{g})$ & $2000 \pm 1.5^{\mathrm{a}}$ & $1900 \pm 9.9^{\mathrm{b}}$ & $2000 \pm 15.0^{\mathrm{a}}$ & 0.05 \\
\% weight Loss & $66.67 \pm 0.5^{\mathrm{a}}$ & $63.33 \pm 0.01^{\mathrm{b}}$ & $66.67 \pm 0.3^{\mathrm{a}}$ & 0.02 \\
\hline
\end{tabular}

Mean in the same row with different superscript differs significantly $(\mathrm{P} \leq 0.05)$. 
J ournal abbreviation: J Food Health Sci

Table 2. Proximate composition of fresh and smoked Clarias gariepinus using fuel wood, cow dung and Corn husks.

\begin{tabular}{lllllll}
\hline Treatment & Moisture (\%) & Ash (\%) & Lipid (\%) & Fibre (\%) & Protein (\%) & NFE (\%) \\
\hline Fresh fish & 68.58 & 1.44 & 5.46 & 2.23 & 17.29 & 5.02 \\
& $\pm 0.01^{\mathrm{a}}$ & $\pm 0.05^{\mathrm{d}}$ & $\pm 0.01^{\mathrm{d}}$ & $\pm 0.02^{\mathrm{d}}$ & $\pm 0.02^{\mathrm{d}}$ & $\pm 0.01^{\mathrm{d}}$ \\
Fuel wood & 11.19 & 5.6 & 14.59 & 4.84 & 51.72 & 12.05 \\
& $\pm 0.02^{\mathrm{b}}$ & $\pm 0.01^{\mathrm{a}}$ & $\pm 0.02^{\mathrm{a}}$ & $\pm 0.01^{\mathrm{a}}$ & $\pm 0.02^{\mathrm{b}}$ & $\pm 0.005^{\mathrm{b}}$ \\
Cow dung & 11.05 & 4.66 & 19.81 & 3.49 & 50.14 & 10.88 \\
& $\pm 0.01^{\mathrm{c}}$ & $\pm 0.00^{\mathrm{b}}$ & $\pm 0.01^{\mathrm{a}}$ & $\pm 0.01^{\mathrm{c}}$ & $\pm 0.01^{\mathrm{c}}$ & $\pm 0.05^{\mathrm{c}}$ \\
Corn husk & 9.42 & 4.43 & 16.33 & 4.27 & 53.25 & 12.32 \\
& $\pm 0.01^{\mathrm{d}}$ & $\pm 0.01^{\mathrm{c}}$ & $\pm 0.05^{\mathrm{b}}$ & $\pm 0.005^{\mathrm{b}}$ & $\pm 0.01^{\mathrm{a}}$ & $\pm 0.005^{\mathrm{a}}$ \\
\hline P. value & 0.01 & 0.01 & 0.01 & 0.01 & 0.01 & 0.01 \\
\hline
\end{tabular}

Mean values in the same column with different superscript varies significantly $(\mathrm{P}<0.05)$.

Table 3. Bacteria count (total plate count) for fish samples smoked with Fuel wood, Cow dung and Corn husks.

\begin{tabular}{lllll}
\hline Parameters & Fuel wood & Cow dung & Corn husk & P-value \\
\hline Bacteria count $(\mathrm{CFU})$ & $1.01 \times 10^{5}$ & $1.81 \times 10^{5}$ & $1.2 \times 10^{5}$ & 0.001 \\
& $\pm 1.0 \times 10^{2 \mathrm{c}}$ & $\pm 4.0 \times 10^{2 \mathrm{a}}$ & $\pm 3.0 \times 10^{2 \mathrm{~b}}$ & \\
\hline
\end{tabular}

Mean in the same row with different superscript differs significantly $(\mathrm{P} \leq 0.05)$

Table 4. Mean hedonic scores for fish samples smoked with fuel wood, cow dung and corn husks.

\begin{tabular}{lllll}
\hline & Fuel wood & Cow dung & Corn husk & P-value \\
\hline Appearance & 4.6 & 3.4 & 3.7 & 0.048 \\
& $\pm 0.27^{\mathrm{a}}$ & $\pm 0.34^{\mathrm{c}}$ & $\pm 0.37^{\mathrm{b}}$ & \\
Aroma & 3.9 & 2.9 & 3.8 & 0.001 \\
& $\pm 0.18^{\mathrm{a}}$ & $\pm 0.36^{\mathrm{b}}$ & $\pm 0.38^{\mathrm{a}}$ & \\
Taste & 4.2 & 3.2 & 3.8 & 0.018 \\
& $\pm 0.23^{\mathrm{a}}$ & $\pm 0.29^{\mathrm{c}}$ & $\pm 0.51^{\mathrm{b}}$ & \\
Texture & 4.2 & 3.3 & 3.5 & 0.14 \\
& \pm 0.13 & \pm 0.33 & \pm 0.43 & \\
\hline
\end{tabular}

Mean in the same row with different superscript differs significantly $(\mathrm{P} \leq 0.05)$.

Fish sample smoked with Cow dung had the highest numbers of bacteria count, This may be due to the fact that Cow dung being an organic waste product had accumulated these organism prior to been used for smoking hence deposited it on the skin (surface) of the fish in the process of smoking. Collins et al. (1999) had earlier reported that Bacillus spp (the organism identified on fish smoked with cow dung and not found on fish smoked with other fuel sources) produces toxic chemicals and can survive certain preparatory processes such as heating and drying due to their endospores and are thus found even on dried foods. However the fact that they were not identified in the other sample means that they were inoculated on the fish from the smoking source hence it may be right to conclude that micro organism isolated on smoke fish differ with smoking source and the type of fish smoked. Omojowo et al. (2009), had earlier reported bacteria flora (Bacillus coagulans, B. cereus, Klebsiella ozanae, Proteus vulgaris, Escherichia coli, Staphylococcus aureus, Streptococcus spp) and fungi (Aspergillus niger, A. candidus, A. flavus and A. nidulan) were isolated in potassium sorbate untreated and smoked tilapia. An experiment on fungal infestation and nutrient quality of smoke-dried Clarias gariepinus, Chrysichthys nigrodigitatus, Sarotherodon galilaeus, Heterotis niloticus, Heterobranchus bidorsalis, Synodontis schall, Synodontis clarias and Clarias anguillaris by Fafioye et al. (2008) revealed Fusarium spp., Aspergillus spp., Rhizopus spp., Mucor spp. and Penicillium spp. as isolated of fungi while bacteria included E. coli, S. aureus and Salmonella spp. of all these micro organisms Aspergillus spp. was found in all the fish samples and 
ranked the most prevalent species. The total bacterial count of the fish smoked with different fuel sources were observed to be within the acceptable range of Aerobic Plate count of $5.0 \times 10^{5} \mathrm{cfu} / \mathrm{g}$ (ICMSF, 1986), however Staphylococci spp observed in fish smoked with fuel wood and corn husk exceeded the recommended level $10^{3} \mathrm{cfu} / \mathrm{g}$. This observation is also in line with the finding of Ayuba et al. (2013).

Organoleptic assessment of smoked samples reveals that in terms of appearance wood source smoked fish were better compared to other smoking sources, the glossy oily appearance observed for the fuel wood smoked sample is in line with the reports of Krasemann (2006) who concluded that smoking fish with soft wood material add appreciable colour to the smoked product. Also Akinneye et al. (2007) in their experiment reported that smoked dried fishes had the most attractive colour compared to oven and sun dried samples. The unattractive colour observed for cow dung may be due to excess deposition of carbon organic waste on the fish skin.

Table 5. Economic Analysis of the cost of smoking fish with Fuel wood, Cow dung and Corn husks

\begin{tabular}{|c|c|c|c|c|c|c|c|c|c|c|c|}
\hline & \multicolumn{3}{|l|}{ Fuel wood } & \multicolumn{4}{|c|}{ Cow dung } & \multicolumn{4}{|c|}{ Corn husk } \\
\hline Input & $\begin{array}{l}\text { Quantity. } \\
\text { kg }\end{array}$ & $\begin{array}{l}\text { Unit } \\
\text { cost. }\end{array}$ & Total & Input & $\begin{array}{l}\text { Quantity. } \\
\text { kg }\end{array}$ & $\begin{array}{l}\text { Unit } \\
\text { cost. }\end{array}$ & Total & Input & $\begin{array}{l}\text { Quantity. } \\
\text { kg }\end{array}$ & $\begin{array}{l}\text { Uni } \\
\text { cost }\end{array}$ & Total \\
\hline Fresh Fish & $3 \mathrm{~kg}$ & 700 & 2100 & Fresh Fish & $3 \mathrm{~kg}$ & 700 & 2100 & Fresh Fish & $3 \mathrm{~kg}$ & 700 & 2100 \\
\hline Fuel wood & $35 \mathrm{~kg}$ & 8.0 & 300 & Cow dung & & & & Corn husk & & & \\
\hline $\begin{array}{l}\text { Matches. Box } \\
\text { Labour }\end{array}$ & 1 & 10 & 10 & $\begin{array}{l}\text { Matches } \\
\text { Labour }\end{array}$ & 1 & 10 & 10 & $\begin{array}{l}\text { Matches } \\
\text { Labour }\end{array}$ & 1 & 10 & 10 \\
\hline Transport & 2 drops & 50 & 100 & Transport & 2 drops & 50 & 100 & Transport & 2 drops & 35 & 70 \\
\hline Total & & & N2510 & Total & & & 2210 & Total & & & 2180 \\
\hline
\end{tabular}

Table 6. Gross profit margin analysis of fish smoked with Fuel wood, Cow dung and Corn husks.

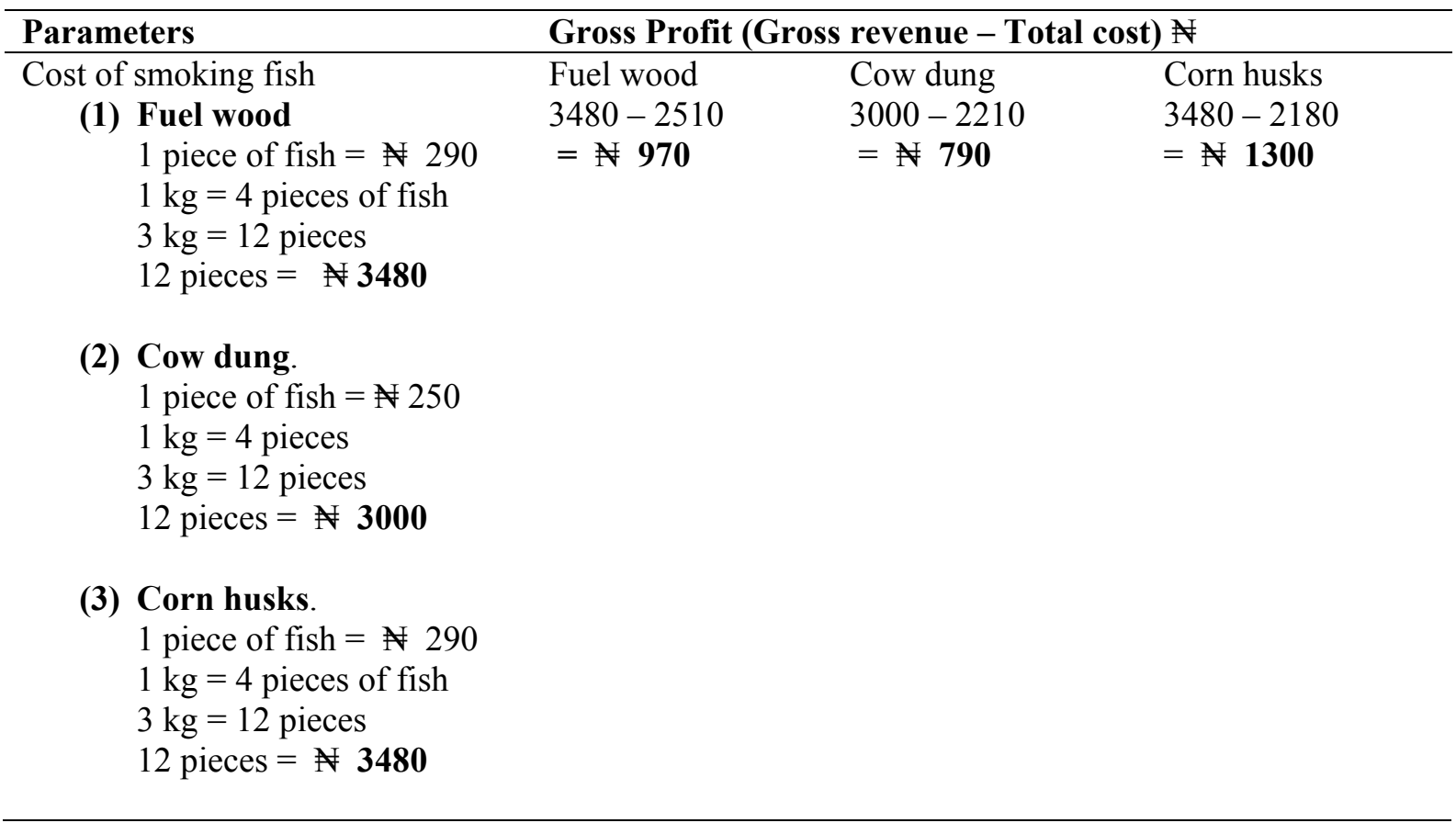


Journal abbreviation: J Food Health Sci

Table 7. Economic analysis of fish smoked with fuel wood, cow dung and corn husks.

\begin{tabular}{lllll}
\hline & Fuel wood & Cow dung & Corn husk & P-value \\
\hline $\begin{array}{l}\text { Amount of smoking } \\
\text { sources used (kg) }\end{array}$ & $35.5 \pm 0.5^{\mathrm{a}}$ & $37.15 \pm 0.35^{\mathrm{a}}$ & $30.5 \pm 0.5^{\mathrm{b}}$ & 0.004 \\
Cost of smoking ( & $2510.0 \pm 12.5^{\mathrm{a}}$ & $2210.0 \pm 5.00^{\mathrm{b}}$ & $2180.0 \pm 15.0^{\mathrm{c}}$ & 0.001 \\
Selling Price (N) & $3480.0 \pm 5.00^{\mathrm{a}}$ & $3000.0 \pm 5.00^{\mathrm{b}}$ & $3480.0 \pm 25.0^{\mathrm{a}}$ & 0.001 \\
Profit (N) & $970.0 \pm 2.5^{\mathrm{b}}$ & $790.0 \pm 20.0^{\mathrm{c}}$ & $1300.0 \pm 5.0^{\mathrm{a}}$ & 0.001 \\
\hline
\end{tabular}

NOTE: Mean in the same row with different superscript differs significantly $(\mathrm{P} \leq 0.05)$

Food colour has been reported to help in determines quality, degree of processing and spoilage as it affect the perception and evaluation by other sense (Norman and Hotchiss, 1996), hence the low score of other organoleptic parameter of the other smoke sources compared to the fuel wood.

The total cost of sample smoked with Fuel wood had a higher cost ( 2510) than the other samples smoked with Cow dung ( 2210) and Corn husks ( 2180) hence making profit of smoking with Corn husks higher (1300) compared to the sample smoked with Fuel wood ( $\$ 970$ ) and Cow dung ( $\$ 790)$.

\section{Conclusion}

The results from this study have shown that corn husks is a better alternative smoking source as it reduce smoking cost, more hygienic processing source, cheaply and readily available.

\section{References}

Abdullahi, M.N. (2011): Organoleptic assessment and proximate composition of Heterobranchus longifilis smoked with various energy sources. Post graduate diploma thesis, University of Agriculture Makurdi.

Akinneye, J.O., Amoo, I.A., Arannilewa, S.I. (2007): Efects of drying methods on the nutritional composition of three species of (Bonga sp, Sardinella sp and Hetrotis niloticus. Journal of Fisheries International, 2(1): 99-103.

AOAC (2000): Official Methods of the Association of Official Analytical Chemist $15^{\text {th }}$ Ed., AOAC, Arlington, Verginia, pp. 275-276.

Ayuba V. O., Alhassan M.I., Jimmy U.U. (2013): Assessment of the microbial load of smoked sardine (Sardina pilchardus, Walbaum, 1792) sold in Makurdi Markets.
International Journal of Current Microbiology and Applied Sciences, 2(9): 277-287

Ayuba, V.O., Omeji, S.O. (2006): Effect of insect infestation on the shelf life of smoked dried fish. Proceedings of the 21st Annual Conference of the Fisheries Society of Nigeria (FISON), Calabar, 13th-1 $17^{\text {th }}$ November, pp. 357359.

Collins, C.H., Grange, J.M., Lyne, P.M. (1999): Fish toxicology. Microbiological methods. pp. 160-171.

Doyle, E.M. (2007): Microbial Food spoilageLosses and Control Strategies. Food Research Institute, University of Wisconsin - Madison, WI 53706.

Eyo, A.A. (2000): Fish processing technology in the tropics. University of Ibadan Press. pp. 165-168.

Eyo, A.A. (2001): Fish Processing Technology in the Tropics. A publication of National Institute for Fresh water Fisheries Research (NIFFR).PMB 6006, New Bussa, Nigeria.

Fafioye, O.O., Fagbohun, T.R., Olubanjo, O.O. (2008): Fungal Infestation and Nutrient Quality of Traditionally Smoke-Dried Freshwater Fish. Turkish Journal of Fisheries and Aquatic Science, 8: 7-13

FSSAI (Food Safety and Standard Authority of India) (2012): Manual of methods of analysis of food and fish products. Lab manual 6. pp 80, available at http://fssai.gov.in/Portals/0/Pdf/15Manuals /MEAT\%20AND\%20FISH.pdf

Garcia, F., Simal, G. (2005): Polycyclic aromatic hydrocarbons in smoke from different woods and their transfer during traditional smoking into chorizo sausages with collagen and tripe casings. Food Additives \& Contaminants, 22: 1-8. 
Giunn, P.J. Cartner, M.E., Makey, B.K., Cartner, G.R. (1999): Clinical Veterinary Microbiology, Virginia, U. S.A.

ICMSF (International Commission on Microbiological Specifications for Food) (1986): Microorganisms in Foods 2, Sampling for Microbiological Analysis: Principles and Specifications 2nd ed. Blackwell science, Oxford. pp 753 -760

Kaneko, S. (1976): Smoked meat and microorganisms. New Food Ind. 18, 17-23. In A review of Japanese studies. Fish smoking and drying. The effict of smoking and drying on the nutritional properties of fish (ed. T. Moto) (1988). Elsevier Applied Science (ed. J. R. Burt), pp. 91-120.

Krasemann, S. (2006): History of fish smoking. http://www.finesalmon.com/Salmon_Food/ A History of Smoke Preservation.asp.

Nerqua ye- Tetieh, G.A., Quashie-Sam, S.L., Dassah, A.L. (2002): Evaluation of fuel wood quality of four tree species used for fish smoking in the Sene District of the Brong Ahafo Region of Ghana. Ghana journal of Agricultural Science 87-94.

Norman, N.P., Joseph, H.H. (1996): Food Science, $5^{\text {th }}$ Edition, Springer publisher pp 593.

Obande, R.A. (2009): Hand book on fish processing and Preservation techniques, swisston digital press, p22.

Okonta, A.A., Ekelemu, J.K. (2005): A preliminary study of micro-organisms associated with fish spoilage in Asaba, Southern Nigeria. Proceedings of the 20th Annual Conference of the Fisheries Society of Nigeria (FISON), Port Harcourt, 14th18th November, 557-560 pp.

Okoso-Amaa, K., Eyeson, K.K., Bonsu, L., Nerquaye-Tetteh, G.A. (1978): Report on the activities of the processing subcommittee. GHI IDRC. Fishery Research and Development Project. Food Research Institute, Accra, Ghana.

Olayemi, F.F, Adedayo, M.R., Bamishaiye, E.I., Awagu, E.F. (2011): Proximate composition of catfish (Clarias gariepinus) smoked in Nigerian stored products research institute (NSPRI): Developed kiln. Int.J. Fisheries and Aquaculture. Vol. 3(5), pp. 95-97, Available online at http://www.academicjournals.org/IJFA.

Omojowo, F.S., Idris, G.L., Ihuahi, J.A. (2009): Comparative Assessment of Potassium Sorbate and Sodium Metabisulphite on the Safety and Shelf Life of Smoked Catfish. Nature and Science, 7(10): 10-17.

Plahar, W.A., Nti, C.A., Steiner-Asiedu, M. (1996): Studies on fish consumption patterns and fish quality at household level in the middle belt districts of Ghana. A Project Report submitted under the Ghana/Netherlands Regional Artisanal Fish Processing and Applied Research Project. Food Research Institute, CSIR, Accra, Ghana

Plahar, W.A., Pace, R.D., Lu, J.Y. (1991): Effects of storage methods on the quality of smoked-dry herring (Sardinella eba). Journal of Science Food and Agriculture, 57: 597-610.

Trade Invests Nigeria, (2010). Trade invests Nigeria News letter Website, March, 2010 Issue 27, published by Africa investment publishing. 